\title{
The Preparation and Characterization of Some Chloro(1,2-ethanediamine)iridium(III) Species
}

\author{
FRODE GALSBØL and BIRGITTE S. RASMUSSEN
}

Chemistry Department I, Inorganic Chemistry, H. C. Ørsted Institute, University of Copenhagen, Universitetsparken 5, DK-2100 Copenhagen Ø, Denmark

An investigation of a published procedure for the preparation of cis- and trans- $\left[\operatorname{Ir}(\mathrm{en})_{2} \mathrm{Cl}_{2}\right] \mathrm{Cl}(\mathrm{en}=$ 1,2-ethanediamine) revealed that besides these species also $\left[\operatorname{Ir}(\mathrm{en}) \mathrm{Cl}_{4}\right]^{-}$and the hitherto unknown mer- $\left[\mathrm{Ir}(\mathrm{en})(\mathrm{enH}) \mathrm{Cl}_{3}\right]^{+} \quad\left(\mathrm{enH}^{+}=2\right.$-aminoethylammonium ion) are formed. The latter is assigned as the meridional geometrical isomer by comparison of the absorption spectrum with that calculated using the angular overlap model. A modified procedure for the isolation of the cis- and trans-isomers in a yield of $\mathrm{ca} .40 \%$ for each is given. The slightly soluble trans- $\left[\operatorname{Ir}(\mathrm{en})_{2} \mathrm{Cl}_{2}\right]_{3}\left[\mathrm{IrCl}_{6}\right] \cdot \mathrm{H}_{2} \mathrm{O}$ has also been prepared. In addition to chemical analysis the compounds have been characterized by thermogravimetry and by their electronic spectra. The concentration acidity constant of mer-[Ir(en)$\left.(\mathrm{enH}) \mathrm{Cl}_{3}\right]^{+}$is estimated to be $10^{-9.12 \pm 0.04} \mathrm{~mol} / \mathrm{l}$ $\left(25^{\circ} \mathrm{C}, 1 \mathrm{M} \mathrm{NaClO}_{4}\right)$.

A survey of the published methods ${ }^{1-4}$ for the preparation of cis- and trans-dichlorobis(1,2ethanediamine)iridium(III) shows that the preparations are cumbersome and/or give low yields. We considered that the procedure published by Baranovskii et $a .^{2}$ was the most promising and tried to reproduce it. However, both the cis- and transisomers isolated by this method were contaminated with red by-products which were very difficult to remove by crystallization. We therefore examined the products of the reaction by chromatography on a cation exchanger. In addition to cis- and trans$\left[\mathrm{Ir}(\mathrm{en})_{2} \mathrm{Cl}_{2}\right]^{+}$(en =1,2-ethanediamine) the mixture contained $\left[\operatorname{Ir}(\mathrm{en}) \mathrm{Cl}_{4}\right]^{-}$and also the hitherto unknown $m e r-\left[\operatorname{Ir}(\mathrm{en})(\mathrm{enH}) \mathrm{Cl}_{3}\right]^{+} \quad\left(\mathrm{enH}^{+}=2-\right.$ aminoethylammonium ion). A procedure is given for the isolation of these compounds.

Furthermore, an alternative method has been developed for the isolation of pure cis- and trans$\left[\operatorname{Ir}(\mathrm{en})_{2} \mathrm{Cl}_{2}\right] \mathrm{Cl}$ in a yield of $c a .40 \%$ for each and the slightly soluble olive green trans$\left[\operatorname{Ir}(\mathrm{en})_{2} \mathrm{Cl}_{2}\right]_{3}\left[\mathrm{IrCl}_{6}\right] \cdot \mathrm{H}_{2} \mathrm{O}$ has been prepared by metathesis. The compounds were identified by chemical analysis, by their electronic spectra and by thermogravimetry.

\section{EXPERIMENTAL}

Materials. Iridium(III) chloride hydrate (ca. 6.6 $\mathrm{mol} \mathrm{H}_{2} \mathrm{O} / \mathrm{mol} \mathrm{Ir}$ ) was obtained from Johnson, Matthey and Co. and 1,2-ethanediamine ("puriss. p.a.") from Fluka. All other chemicals were of analytical or reagent grade and were used without further purification.

Instrumentation. Absorption spectra were recorded on a Cary 118C spectrophotometer. Thermogravimetric measurements were performed on the thermobalance described by Pedersen. ${ }^{5}$

\section{Synthetic Procedures}

1. cis- and trans- $\left[\operatorname{Ir}(\text { en })_{2} \mathrm{Cl}_{2}\right]^{+}$, mer- $[\operatorname{Ir}($ en $)$ (enH) $\left.\mathrm{Cl}_{3}\right]^{+}$and $\left[\mathrm{Ir}(\mathrm{en}) \mathrm{Cl}_{4}\right]^{-}$. A $6.40 \mathrm{~g}$ sample of $\mathrm{IrCl}_{3} \cdot 6.6 \mathrm{H}_{2} \mathrm{O}(15.3 \mathrm{mmol})$ is dissolved in $50 \mathrm{ml}$ of water by heating to boiling in a $250 \mathrm{ml}$ flask fitted with a condenser. Then a mixture of $2.6 \mathrm{ml}$ of 1,2 ethanediamine $(39 \mathrm{mmol})$ and $4.4 \mathrm{ml}$ of acetic acid ( $77 \mathrm{mmol}$ ) diluted to $50 \mathrm{ml}$ with water is added with reflux over a period of $c a .10 \mathrm{~min}$. The refluxing is continued for a further $10 \mathrm{~h}$ after which the reddish brown reaction mixture is filtered, and the filter washed thoroughly with water. The filtrate and washings are evaporated to dryness on a rotating vacuum evaporator, RVE, (final bath temperature $50^{\circ} \mathrm{C}$ ), and the residue is dissolved in $20 \mathrm{ml}$ of boiling water. $25 \mathrm{ml}$ of $12 \mathrm{M} \mathrm{HCl}$ are added to the hot 
solution (if the solution is boiled an olive green precipitate of the slightly soluble trans$\left[\operatorname{Ir}(\mathrm{en})_{2} \mathrm{Cl}_{2}\right]_{3}\left[\mathrm{IrCl}_{6}\right] \cdot \mathrm{H}_{2} \mathrm{O}$ is formed) and the solution is again evaporated to dryness on an RVE (final bath temperature $90^{\circ} \mathrm{C}$ ).

The orange residue is dissolved in $10 \mathrm{ml}$ of boiling water. The solution is allowed to stand for crystallization, first at room temperature, then in the refrigerator overnight, and is finally cooled in ice. The orange crystals are filtered and washed, first with two $1 \mathrm{ml}$ portions of ice-cold water, then with ethanol, finally with ether, and dried in air (product A). The filtrate and washings are evaporated to dryness on an RVE (final bath temperature $50^{\circ} \mathrm{C}$ ). The residue is boiled with $5 \mathrm{ml}$ of water, and $7.5 \mathrm{ml}$ of $12 \mathrm{M} \mathrm{HCl}$ are added. The solution is allowed to stand for crystallization, first at room temperature, then in the refrigerator overnight, and is finally cooled in ice. The crystals are filtered and washed, first with two $1 \mathrm{ml}$ portions of ice-cold $6 \mathrm{M} \mathrm{HCl}$, then with ethanol, finally with ether, and dried in air (product B).

The products $\mathrm{A}$ and $\mathrm{B}(\mathrm{ca} .6 \mathrm{~g})$ are mixed and dissolved in $500 \mathrm{ml}$ of water and $12 \mathrm{M} \mathrm{HCl}$ is added until $\mathrm{pH}=c a .2$ ( $c a .0 .4 \mathrm{ml})$. The solution is filtered and the filtrate is applied on a column of $30 \mathrm{~g}$ of SPSephadex C-25 cation exchanger $\left(\mathrm{Li}^{+}\right.$-form, $\mathrm{ca} .60$ $\mathrm{cm}$ long and $c a .2 \mathrm{~cm}$ diameter) which is then washed with water until the eluate which contains the red $\left[\mathrm{Ir}(\mathrm{en}) \mathrm{Cl}_{4}\right]^{-}$, fraction I, is colourless. The column is then eluted with $0.02 \mathrm{M} \mathrm{LiOH}$, which will neutralize $\left[\operatorname{Ir}(\mathrm{en})(\mathrm{enH}) \mathrm{Cl}_{3}\right]^{+}$(usually more than $500 \mathrm{ml}$ are necessary) and the golden coloured fraction II containing $\left[\operatorname{Ir}(\mathrm{en})\left(\mathrm{en}^{*}\right) \mathrm{Cl}_{3}\right]\left(\mathrm{en}^{*}=\right.$ unidentate $1,2-$ ethanediamine) is collected. The column is then washed with $200 \mathrm{ml}$ of water and finally the yellow band, containing cis- and trans- $\left[\operatorname{Ir}(\mathrm{en})_{2} \mathrm{Cl}_{2}\right]^{+}$, is eluted with $0.25 \mathrm{M} \mathrm{LiCl}$. The yellow fraction III is collected.

Fraction I is acidified with $2 \mathrm{ml}$ of $12 \mathrm{M} \mathrm{HCl}$, before it is evaporated to a volume of $c a .10 \mathrm{ml}$.* Then $3 \mathrm{ml}$ of $2 \mathrm{M} \mathrm{KOH}$ are added and the solution is evaporated to dryness on an RVE (final bath temperature $50^{\circ} \mathrm{C}$ ). $\mathrm{LiCl}$ and $\mathrm{HCl}$ are extracted by boiling with $20 \mathrm{ml}$ of absolute ethanol followed by filtration and washing with absolute ethanol. The residue is dissolved in the minimum volume ( $c a .5$ $\mathrm{ml}$ ) of boiling $0.1 \mathrm{M} \mathrm{HCl}$ and the solution is allowed to stand overnight for crystallization. The precipitate is filtered and washed, first with two 0.5 $\mathrm{ml}$ portions of ice-cold water, then with ethanol,

* If the solution is not acidic the pink compound $\left(\operatorname{Ir}(\mathrm{en}) \mathrm{Cl}_{3}\right)_{x}$ is precipitated. ${ }^{11}$ This compound can be reconverted to $\left[\mathrm{Ir}(\mathrm{en}) \mathrm{Cl}_{4}\right]^{-}$by boiling with $2 \mathrm{M} \mathrm{HCl}$. In the analytical data for $\left(\operatorname{Ir}(\mathrm{en}) \mathrm{Cl}_{3}\right)_{x}$ given in $\mathrm{Ref} .11$ it seems likely that the values found for $\mathrm{C}$ and $\mathrm{N}$ have been interchanged. finally ether, and dried in air. Yield $0.7 \mathrm{~g}(10 \%)$ of reddish orange $\mathrm{K}\left[\mathrm{Ir}(\mathrm{en}) \mathrm{Cl}_{4}\right] \cdot 2 \mathrm{H}_{2} \mathrm{O}$. (Found: $\mathrm{C} 5.17$; $\mathrm{H} 2.47 ; \mathrm{N} 5.88 ; \mathrm{Cl} 30.45 ; \mathrm{K}$ 8.29. Calc. for $\mathrm{KIrC}_{2} \mathrm{H}_{12} \mathrm{~N}_{2} \mathrm{Cl}_{4} \mathrm{O}_{2}: \mathrm{C} 5.12 ; \mathrm{H} 2.58 ; \mathrm{N} 5.97 ; \mathrm{Cl}$ $30.22 ; \mathrm{K} 8.33$ ). Thermogravimetry: loss of weight $81.0 \mathrm{mg} / \mathrm{g}$ sample, i.e. $38.2 \mathrm{~g} / \mathrm{mol}$.

Fraction II is acidified with $\mathrm{HCl}$ and evaporated to dryness on an RVE (final bath temperature $50^{\circ} \mathrm{C}$ ). $\mathrm{LiCl}$ is extracted by boiling with $20 \mathrm{ml}$ of absolute ethanol followed by filtration and washing with absolute ethanol. The residue is dissolved in the minimum volume (ca. $3 \mathrm{ml}$ ) of boiling water and the solution is allowed to stand overnight for crystallization. The precipitate is filtered, washed with two $1 \mathrm{ml}$ portions of ice-cold water, and dried in air. Yield $1.5 \mathrm{~g}(21 \%)$ of orange mer$\left[\operatorname{Ir}(\mathrm{en})(\mathrm{enH}) \mathrm{Cl}_{3}\right] \mathrm{Cl} . \mathrm{H}_{2} \mathrm{O}$. (Found: $\mathrm{C} 10.17 ; \mathbf{H} 3.86 ; \mathrm{N}$ 11.94; Cl(tot.) 29.18; Cl(ion.) 7.55. Calc. for $\mathrm{IrC}_{4} \mathrm{H}_{19} \mathrm{~N}_{4} \mathrm{Cl}_{4} \mathrm{O}: \mathrm{C} 10.15 ; \mathrm{H} 4.05 ; \mathrm{N} 11.84 ; \mathrm{Cl}$ (tot.) 29.97; Cl(ion.) 7.49). Thermogravimetry: loss of weight $39.0 \mathrm{mg} / \mathrm{g}$ sample, i.e. $18.5 \mathrm{~g} / \mathrm{mol}$.

Fraction III is acidified with $\mathrm{HCl}$ and evaporated to dryness on an RVE (final bath temperature $50^{\circ} \mathrm{C}$ ). $\mathrm{LiCl}$ is extracted by boiling with $30 \mathrm{ml}$ of absolute ethanol followed by cooling, filtration, and washing with absolute ethanol. The residue is dissolved in the minimum volume (ca. $4 \mathrm{ml}$ ) of boiling water and the solution is allowed to stand overnight for crystallization. The precipitate is filtered, washed with $1 \mathrm{ml}$ of ice-cold water, and dried in air. Yield 1.5 g $(22 \%)$ of pale yellow cis-[Ir(en $\left.)_{2} \mathrm{Cl}_{2}\right] \mathrm{Cl}_{2} \mathrm{H}_{2} \mathrm{O}$. (Found: C 11.04; H 4.25; N 12.79; Cl(tot.) 24.60; Cl(ion.) 8.16. Calc. for $\operatorname{IrC}_{4} \mathrm{H}_{18} \mathrm{~N}_{4} \mathrm{Cl}_{3} \mathrm{O}: \mathrm{C} 11.00 ; \mathrm{H}$ 4.15; $\mathrm{N} 12.83$; $\mathrm{Cl}$ (tot.) 24.35; $\mathrm{Cl}$ (ion.) 8.12). Thermogravimetry: loss of weight $48.4 \mathrm{mg} / \mathrm{g}$ sample, i.e. $21.3 \mathrm{~g} / \mathrm{mol}$.

The filtrate and washings are heated to boiling and 1.5 volumes of $12 \mathrm{M} \mathrm{HCl}$ are added. The solution is allowed to stand at room temperature for crystallization, and is finally cooled in ice. The precipitate (trans- $\left[\mathrm{Ir}(\mathrm{en})_{2} \mathrm{Cl}_{2}\right] \mathrm{Cl} \cdot \mathrm{HCl} \cdot 2 \mathrm{H}_{2} \mathrm{O}$ ) is filtered and washed, first with two $0.5 \mathrm{ml}$ portions of 6 $\mathrm{M} \mathrm{HCl}$, then with ethanol, finally with ether, and dried at $135^{\circ} \mathrm{C}$. Yield $0.8 \mathrm{~g}(12 \%)$ of yellow trans$\left[\mathrm{Ir}(\mathrm{en})_{2} \mathrm{Cl}_{2}\right.$ ] Cl. (Found: $\mathrm{C} 11.51 ; \mathrm{H}$ 3.92; $\mathrm{N} \mathrm{13.39}$; Cl(tot.) 25.35; Cl(ion.) 8.51. Calc. for $\operatorname{IrC}_{4} \mathrm{H}_{16} \mathrm{~N}_{4} \mathrm{Cl}_{3}$ : C 11.47; H 3.85; N 13.38; Cl(tot.) 25.40; Cl(ion.) 8.47). By recrystallization from water $(c a .0 .6 \mathrm{ml} / \mathrm{g})$ the monohydrate is obtained. Anal. $\operatorname{IrC}_{4} \mathrm{H}_{18} \mathrm{~N}_{4} \mathrm{Cl}{ }_{3} \mathrm{O}: \mathrm{C}$, $\mathrm{H}, \mathrm{N}, \mathrm{Cl}$ (tot.), $\mathrm{Cl}($ ion.). Thermogravimetry: loss of weight $42.7 \mathrm{mg} / \mathrm{g}$ sample, i.e. $18.7 \mathrm{~g} / \mathrm{mol}$.

2. Dichlorobis (1,2-ethanediamine) iridium (III) chlorides. A $6.40 \mathrm{~g}$ sample of $\mathrm{IrCl}_{3} \cdot 6.6 \mathrm{H}_{2} \mathrm{O}(15.3 \mathrm{mmol})$ is dissolved in a mixture of $0.9 \mathrm{ml}$ of acetic acid (16 $\mathrm{mmol}$ ) and $17 \mathrm{ml}$ of water by heating to boiling in a $50 \mathrm{ml}$ flask fitted with a condenser. Then $3.1 \mathrm{ml}$ of 1,2-ethanediamine ( $46 \mathrm{mmol}$ ), diluted to $6 \mathrm{ml}$ with water, are added with reflux: first $1 \mathrm{ml}$ then $0.5 \mathrm{ml}$ 
every half hour. After the last addition the solution is refluxed for further $5 \mathrm{~h}$ and then evaporated to dryness on an RVE (final bath temperature $90^{\circ} \mathrm{C}$ ). The solid brown residue is heated to $170^{\circ} \mathrm{C}$ for $24 \mathrm{~h}$ and is then dissolved in $20 \mathrm{ml}$ of boiling water. The solution is filtered, flask and filter are washed with two $10 \mathrm{ml}$ portions of boiling water, and the filtrate and washings are evaporated to dryness on an RVE. The residue is dissolved in $10 \mathrm{ml}$ of boiling water and the solution is allowed to stand for crystallization, first $2 \mathrm{~h}$ at room temperature then in the refrigerator overnight. The crystal cake is then broken up and the mixture is cooled in ice-water for $3 \mathrm{~h}$ before the crystals are filtered, washed with two $1 \mathrm{ml}$ portions of ice-cold water, and dried in air. Yield $2.5 \mathrm{~g}(37 \%)$ of cis-[Ir(en) $\left.{ }_{2} \mathrm{Cl}_{2}\right] \mathrm{Cl} . \mathrm{H}_{2} \mathrm{O}$. ${ }^{*}$ Anal. $\mathrm{IrC}_{4} \mathrm{H}_{18} \mathrm{~N}_{4} \mathrm{Cl}_{3} \mathrm{O}$ : $\mathrm{C}, \mathrm{H}, \mathrm{N}, \mathrm{Cl}$ (tot.), Cl(ion.).

The combined filtrate and washings are heated to boiling, $20 \mathrm{ml}$ of $12 \mathrm{M} \mathrm{HCl}$ are added, and the mixture is allowed to stand at room temperature for $1 \mathrm{~h}$ before it is cooled in ice for $2 \mathrm{~h}$. The crystals are filtered and washed, first with two $3 \mathrm{ml}$ portions of ice-cold $6 \mathrm{M} \mathrm{HCl}$,** then with ethanol, finally with ether. The yellow product is dried at $135^{\circ} \mathrm{C}$. Yield $2.5 \mathrm{~g}(39 \%)$ of trans-[Ir(en $\left.)_{2} \mathrm{Cl}_{2}\right] \mathrm{Cl}$. Anal. $\mathrm{IrC}_{4} \mathrm{H}_{16} \mathrm{~N}_{4} \mathrm{Cl}_{3}: \mathrm{C}, \mathrm{H}, \mathrm{N}, \mathrm{Cl}$.

3. trans-Dichlorobis( 1,2-ethanediamine)iridium (III) hexachloroiridate(III), monohydrate. $10 \mathrm{ml}$ of $12 \mathrm{M}$ $\mathrm{HCl}$ are added to a solution of $0.25 \mathrm{~g}$ of $\mathrm{IrCl}_{3} \cdot 6.6 \mathrm{H}_{2} \mathrm{O}$ $(0.60 \mathrm{mmol})$ in $5 \mathrm{ml}$ of boiling water. The mixture is heated to boiling and a hot solution of $0.75 \mathrm{~g}$ of trans$\left[\operatorname{Ir}(\mathrm{en})_{2} \mathrm{Cl}_{2}\right] \mathrm{Cl}(1.8 \mathrm{mmol})$ in $5 \mathrm{ml}$ of water is added. The solution is heated to boiling and then allowed to stand overnight for crystallization. The olive green precipitate is then filtered, washed thoroughly with water, and dried in air. Yield $0.82 \mathrm{~g}(87 \%)$ of trans$\left[\operatorname{Ir}(\mathrm{en})_{2} \mathrm{Cl}_{2}\right]_{3}\left[\mathrm{IrCl}_{6}\right] \cdot \mathrm{H}_{2} \mathrm{O}$. (Found: C 9.16; H 3.28; $\mathrm{N} 10.71 ; \mathrm{Cl} 27.38$. Calc. for $\mathrm{Ir}_{4} \mathrm{C}_{12} \mathrm{H}_{50} \mathrm{~N}_{12} \mathrm{Cl}_{12} \mathrm{O}: \mathrm{C}$ $9.16 ; \mathrm{H} 3.20 ; \mathrm{N} 10.69 ; \mathrm{Cl} 27.05)$. Thermogravimetry: loss of weight $15.0 \mathrm{mg} / \mathrm{g}$ sample, i.e. $23.6 \mathrm{~g} / \mathrm{mol}$.

\section{RESULTS AND DISCUSSION}

The content of water (and $\mathrm{HCl}$ ) of crystallization was determined by thermogravimetry. Fig. 1 shows the results for trans- $\left[\operatorname{Ir}(\mathrm{en})_{2} \mathrm{Cl}_{2}\right] \mathrm{Cl} \cdot \mathrm{HCl} .2 \mathrm{H}_{2} \mathrm{O}$ and

*Both (+)- $\alpha$-bromocamphor- $\pi$-sulfonic acid and $(+)_{546}^{\mathrm{RD}}$-ethylenediaminetetraacetatocobaltate(III) have been reported ${ }^{4,9}$ as resolving agents for cis- $\left[\mathrm{Ir}(\mathrm{en})_{2} \mathrm{Cl}_{2}\right]^{+}$.

** If the washing with ethanol and ether is omitted and the product is dried in air, trans- $\left[\mathrm{Ir}(\mathrm{en})_{2} \mathrm{Cl}_{2}\right] \mathrm{Cl} . \mathrm{HCl} \cdot 2 \mathrm{H}_{2} \mathrm{O}$ is obtained. Yield $2.6 \mathrm{~g} \mathrm{(39 \% )}$. (Found: $\mathrm{C} \mathrm{9.65;} \mathrm{H} 4.23 ; \mathrm{N}$ 11.43; Cl(tot.) $28.62 ; \mathrm{Cl}$ (ion.) $14.44 ; \mathrm{H}^{+} 2.037 \mathrm{mmol} / \mathrm{g}$. Calc. for $\mathrm{IrC}_{4} \mathrm{H}_{21} \mathrm{~N}_{4} \mathrm{Cl}_{4} \mathrm{O}_{2}$ : C 9.78; $\mathrm{H} \mathrm{4.31;} \mathrm{N} \mathrm{11.41;} \mathrm{Cl(tot.)}$ 28.87; Cl(ion.) 14.43; $\mathrm{H}^{+} 2.036 \mathrm{mmol} / \mathrm{g}$ ). Thermogravimetry: loss of weight $155 \mathrm{mg} / \mathrm{g}$ sample, i.e. $76.7 \mathrm{~g} / \mathrm{mol}$.

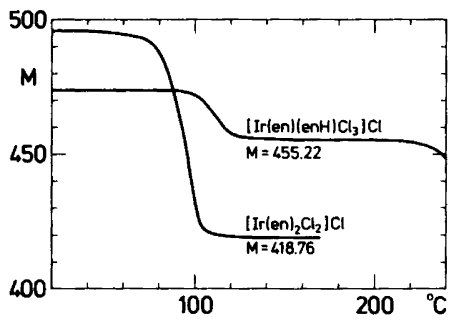

Fig. 1. Thermogravimetric analysis of trans$\left[\mathrm{Ir}(\mathrm{en})_{2} \mathrm{Cl}_{2}\right] \mathrm{Cl} . \mathrm{HCl} .2 \mathrm{H}_{2} \mathrm{O}$ and $m e r-\left[\mathrm{Ir}(\mathrm{en})(\mathrm{enH}) \mathrm{Cl}_{3}\right]-$ $\mathrm{Cl} . \mathrm{H}_{2} \mathrm{O}$ in air. Heating rate $2^{\circ} \mathrm{C} / \mathrm{min}$. The ordinate gives a number which is proportional to the sample weight, so that the value at the plateau to the right equals the molecular weight of the material without water $($ and $\mathrm{HCl})$ of crystallization.

$m e r-\left[\operatorname{Ir}(e n)(e n H) \mathrm{Cl}_{3}\right] \mathrm{Cl}_{2} \mathrm{H}_{2} \mathrm{O}$. The curves for the other three compounds are similar in shape. The compounds start to loose water of crystallization at the following approximate temperatures: $\mathrm{K}$ $\left[\operatorname{Ir}(\mathrm{en}) \mathrm{Cl}_{4}\right] \cdot 2 \mathrm{H}_{2} \mathrm{O}: 50^{\circ} \mathrm{C}$, cis- and trans- $\left[\operatorname{Ir}(\mathrm{en})_{2} \mathrm{Cl}_{2}\right]-$ $\mathrm{Cl} \cdot \mathrm{H}_{2} \mathrm{O}: 60^{\circ} \mathrm{C}$, and trans- $\left[\operatorname{Ir}(\mathrm{en})_{2} \mathrm{Cl}_{2}\right]_{3}\left[\mathrm{IrCl}_{6}\right] \cdot \mathrm{H}_{2} \mathrm{O}$ : $45^{\circ} \mathrm{C}$.

The absorption spectra of cis- and trans-[Ir$\left.(\mathrm{en})_{2} \mathrm{Cl}_{2}\right] \mathrm{Cl}_{2} \mathrm{H}_{2} \mathrm{O}$ are shown in Fig. 2. They are in good agreement with earlier published results. ${ }^{1,4,6-10}$ Fig. 3 shows the absorption spectra of $\mathrm{K}\left[\mathrm{Ir}(\mathrm{en}) \mathrm{Cl}_{4}\right] \cdot 2 \mathrm{H}_{2} \mathrm{O}$ and $m e r-\left[\operatorname{Ir}(\mathrm{en})(\mathrm{enH}) \mathrm{Cl}_{3}\right]$ $\mathrm{Cl}_{2} \mathrm{H}_{2} \mathrm{O}$. Baranovskii et al. ${ }^{11}$ reports maxima at 320,369 and $498 \mathrm{~nm}$ for the former. The latter compound is assigned as the meridional geometrical isomer by comparison of the absorp-

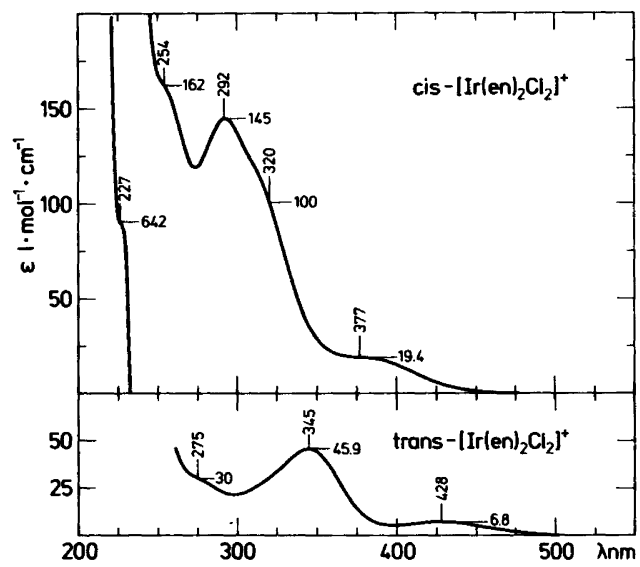

Fig. 2. The absorption spectra of cis- and trans$\left[\mathrm{Ir}(\mathrm{en})_{2} \mathrm{Cl}_{2}\right] \mathrm{Cl}_{2} \mathrm{H}_{2} \mathrm{O}$. 


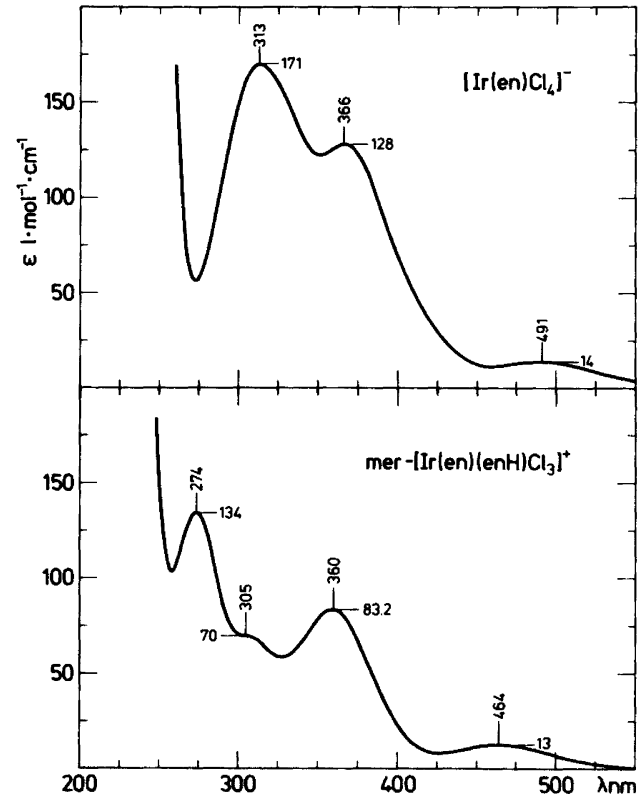

Fig. 3. The absorption spectra of $\mathrm{K}\left[\mathrm{Ir}(\mathrm{en}) \mathrm{Cl}_{4}\right] \cdot 2 \mathrm{H}_{2} \mathrm{O}$ and $m e r-\left[\operatorname{Ir}(\mathrm{en})(\mathrm{enH}) \mathrm{Cl}_{3}\right] \mathrm{Cl}_{2} \mathrm{H}_{2} \mathrm{O}$. tion spectrum with the transitions calculated using the angular overlap model (Fig. 4). The calculations of the transition energies are based on the expanded radial function model ${ }^{12}$ for the $d^{6}$ system, where the energy level ${ }^{1} A_{1 g}\left(O_{h}\right)$ is assigned the $t_{2 g}^{6}$ configuration and both ${ }^{1} T_{1 g}\left(O_{h}\right)$ and ${ }^{1} T_{2 g}\left(O_{h}\right)$ the $t_{2}^{5} e$ configuration. The center of gravity rule is lost, because of the non-diagonal elements between ${ }^{1} T_{1 g}\left(O_{h}\right)$ and ${ }^{1} T_{2 g}\left(O_{h}\right)$, which have been taken into account in this model. The connecting lines show the cubic parentage of the energy levels. The holohedric symmetry $D_{4 h}$ for cis- $\mathrm{N}_{4} \mathrm{Cl}_{2}$ and cis- $\mathrm{N}_{2} \mathrm{Cl}_{4}$ and $O_{h}$ for fac $-\mathrm{N}_{3} \mathrm{Cl}_{3}$ accounts for the degeneracies of the energy levels. As seen from Fig. 4, there is a reasonably good agreement between the calculated and the observed transition energies. It should be noted that in the cis- $\mathrm{N}_{2} \mathrm{Cl}_{4}$ case, the calculations show an absorption band at $36.7 \times 10^{3} \mathrm{~cm}^{-1}(272$ $\mathrm{nm}$ ), where the spectrum (Fig. 3) shows a very narrow minimum; however, only $1000 \mathrm{~cm}^{-1}$ uncertainty in the calculations would change the calculated value to $37700 \mathrm{~cm}^{-1}(265 \mathrm{~nm})$ or 35700 $\mathrm{cm}^{-1}(280 \mathrm{~nm})$ and at both these places the experimental spectrum could accommodate a band

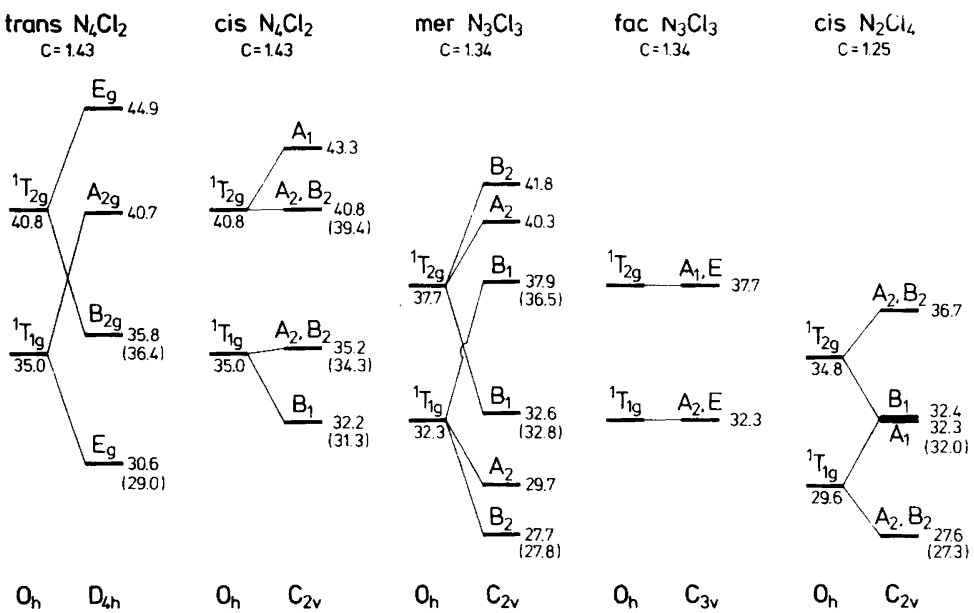

Fig. 4. Comparison of calculated and experimental (in parentheses) transition energies for some $\left[\mathrm{IrN} \mathrm{N}_{x} \mathrm{Cl}_{6-x}\right]^{x-3}$ species. All energies in the figure are given in $1000 \mathrm{~cm}^{-1}$ units. The calculated values were obtained by using the angular overlap model matrices published by Schäffer and Jørgensen, ${ }^{12}$ the relations $\Delta=\sigma+C=\Delta_{\sigma}-\Delta_{\pi}, C=4 B, \Delta_{\sigma}=3 e_{\sigma}^{\prime}$, and $\Delta_{\pi}=4 e_{\pi}^{\prime}$ and the following parameters $\sigma_{\mathrm{Cl}_{6}}=24.1 \times 10^{3} \mathrm{~cm}^{-1}$ (Ref. 14), $B_{\mathrm{Cl} 1}=265 \mathrm{~cm}^{-1}$, and $\Delta_{\pi \mathrm{Cl}}=1 \times 10^{3} \mathrm{~cm}^{-1}$ i.e. $\Delta_{\sigma \mathrm{Cl}}=26.2 \times 10^{3} \mathrm{~cm}^{-1}$, and $\sigma_{\mathrm{N}}=40.5 \times 10^{3} \mathrm{~cm}^{-1}$ (Ref. 15), $B_{\mathrm{N}_{6}}=405 \mathrm{~cm}^{-1}$, and $\Delta_{\pi \mathrm{N}}=0$ i.e. $\Delta_{\sigma \mathrm{N}}=42.1 \times 10^{3} \mathrm{~cm}^{-1}$. The $C_{\mathrm{N}_{x} \mathrm{Cl}_{6-x}}$-values have been calculated by linear interpolation between the $C_{\mathrm{Cl}_{6}}-$ and $C_{\mathrm{N}_{6}}$-values. 
Table 1. Concentration acidity constants of the 1,2-ethanediammonium ion and of various complexes containing the 2-aminoethylammonium moiety.

\begin{tabular}{|c|c|c|c|}
\hline Acid & $\mathrm{p} K_{\mathrm{a}}$ & Medium & Ref. \\
\hline \multirow[t]{4}{*}{$\mathrm{enH}^{+}$} & 10.17 & $1 \mathrm{M} \mathrm{KNO}_{3}$ & 18 \\
\hline & 10.06 & $1 \mathrm{M} \mathrm{KCl}$ & 19 \\
\hline & 10.16 & $1 \mathrm{M} \mathrm{NaCl}$ & 20 \\
\hline & 10.03 & $\mathrm{I}=0.1 \mathrm{M}$ & 21 \\
\hline \multirow[t]{4}{*}{$\mathrm{enH}_{2}^{2+}$} & 7.49 & $1 \mathrm{M} \mathrm{KNO}_{3}$ & 18 \\
\hline & 7.44 & $1 \mathrm{M} \mathrm{KCl}$ & 19 \\
\hline & 7.52 & $1 \mathrm{M} \mathrm{NaCl}$ & 20 \\
\hline & 7.22 & $\mathrm{I}=0.1 \mathrm{M}$ & 21 \\
\hline $\mathrm{Ag}(\mathrm{enH})^{2+}$ & 8.98 & $\mathrm{I}=0.1 \mathrm{M}$ & 21 \\
\hline $\mathrm{Hg}(\mathrm{enH})^{3+}$ & 8.2 & $1 \mathrm{M} \mathrm{KNO}_{3}$ & 18 \\
\hline$\left(\mathrm{NH}_{3}\right)_{5} \mathrm{CrOCr}\left(\mathrm{NH}_{3}\right)_{4}(\mathrm{enH})^{5+}$ & 8.42 & $0.1 \mathrm{M} \mathrm{KCl}^{\circ}$ & 22 \\
\hline$\left(\mathrm{NH}_{3}\right) \mathrm{PtCl}_{2}(\mathrm{enH})^{+}$ & ca. 7 & $1 \mathrm{M} \mathrm{KCl}$ & 23 \\
\hline $\mathrm{Cr}(\mathrm{en})_{2}(\mathrm{OH})(\mathrm{enH})^{3+}$ & 8.8 & $0.25 \mathrm{M} \mathrm{NH}_{4} \mathrm{Cl}$ & 20 \\
\hline$m e r-\operatorname{Ir}(\mathrm{en}) \mathrm{Cl}_{3}(\mathrm{enH})^{+}$ & 9.12 & $1 \mathrm{M} \mathrm{NaClO}_{4}$ & This work \\
\hline
\end{tabular}

component. The $B$ values were estimated from the complete $d^{6}$ matrices for $O_{h}$-symmetry, ${ }^{13}$ assuming $C=4 B$ and using the first $\left({ }^{1} A_{1 g} \rightarrow{ }^{1} T_{1 g}\right)$ and second $\left({ }^{1} A_{1 g} \rightarrow{ }^{1} T_{2 g}\right)$ transition energies $24.1 \times 10^{3} \mathrm{~cm}^{-1}$ and $28.1 \times 10^{3} \mathrm{~cm}^{-1}$ (Ref. 14) for $\left[\mathrm{IrCl}_{6}\right]^{3-}$ and 40.5 $\times 10^{3} \mathrm{~cm}^{-1}$ (Ref. 15) for $\left[\operatorname{Ir}(\mathrm{en})_{3}\right]^{3+}$ and $46.7 \times 10^{3}$ $\mathrm{cm}^{-1}$ (Ref. 16) for $\left[\operatorname{Ir}\left(\mathrm{NH}_{3}\right)_{6}\right]^{3+}$. We have used the energy of the second spin allowed transition band for $\left[\operatorname{Ir}\left(\mathrm{NH}_{3}\right)_{6}\right]^{3+}$, firstly, because the ${ }^{1} A_{1 g} \rightarrow^{1} T_{2 g}$ transition for $\left[\operatorname{Ir}(\mathrm{en})_{3}\right]^{3+}$ only appears as a shoulder in the spectrum, ${ }^{15}$ secondly, because in both the analogous $\mathrm{CoN}_{6}$ and $\mathrm{RhN}_{6}$ chromophores of $d^{6}$ configuration the ${ }^{1} A_{1 g} \rightarrow{ }^{1} T_{2 g}$ transition is observed at the same energy.

An X-ray crystal structure analysis of $\left[\mathrm{Ir}(\mathrm{en})(\mathrm{enH}) \mathrm{Cl}_{3}\right] \mathrm{Cl}_{\mathrm{H}} \mathrm{H}_{2} \mathrm{O}$ is presently being made.

The concentration acidity constant of mer$\left[\mathrm{Ir}(\mathrm{en})(\mathrm{enH}) \mathrm{Cl}_{3}\right]^{+}\left(1.0 \mathrm{M} \mathrm{NaClO}{ }_{4}, 25.0^{\circ} \mathrm{C}\right)$ was estimated to be $10^{-9.12 \pm 0.04} \mathrm{~mol} / \mathrm{l}$ by regression analysis of the titration data as described by Mønsted and Mønsted. ${ }^{17} \mathrm{~A}$ comparison with relevant literature data is shown in Table 1 .

Acknowledgements. The authors wish to thank Dr. Ole Mønsted for borrowing his regression analysis computer program and Prof. Claus Schäffer for many valuable discussions of the spectral data. We also thank Johnson, Matthey \& $\mathrm{Co}$. for a loan of the iridium chloride used in these studies.

\section{REFERENCES}

1. Kida, S. Bull. Chem. Soc. Jpn. 39 (1966) 2415.

2. Baranovskii, I. B., Kovalenko, G. S. and Babaeva, A. V. Russ. J. Inorg. Chem. 13 (1968) 1708.

3. Bauer, R. A. and Basolo, F. Chem. Commun. (1968) 458.

4. Bauer, R. A. and Basolo, F. Inorg. Chem. 8 (1969) 2231.

5. Pedersen, E. J. Sci. Instrum. 1 (1968) 1013.

6. Baranovskii, I. B., Kovalenko, G. S. and Babaeva, A. V. Russ. J. Inorg. Chem. 14 (1969) 1478.

7. DeArmond, M.K. and Hillis, J. E. J.Chem. Phys. 54 (1971) 2247.

8. Blanchard, W. D. and Mason, W. R. Inorg. Chim. Acta 28 (1978) 159.

9. Ogino, H. and Bailar, J. C., Jr. Inorg. Chem. 17 (1978) 1118.

10. Telebinasab-Sarvari, M. and Ford, P. C. Inorg. Chem. 19 (1980) 2640.

11. Baranovskii, I. B., Sevast'yanova, R. E., Mazo, G. Y. and Nefedov, V. I. Russ. J. Inorg. Chem. 19 (1974) 1535.

12. Schäffer, C. E. and Jørgensen, C. K. K. Dan. Vidensk. Selsk., Mat.-Fys. Medd. 34 (1965) No. 13.

13. Tanabe, Y. and Sugano, S. J. Phys. Soc. Jpn. 9 (1954) 753.

14. Jørgensen, C. K. Acta Chem. Scand. 10 (1956) 500.

15. Galsbøl, F. and Rasmussen, B. S. Acta Chem. Scand. A 36 (1982) 83.

16. Schmidtke, H.-H. J. Mol. Spectrosc. 11 (1963) 483.

17. Mønsted, L. and Mønsted, O. Acta Chem. Scand. A 30 (1976) 203. 
18. Bjerrum, J. and Larsen, E. In Schneider, W., Anderegg, G. and Gut, R., Eds., Essays in Coordination Chemistry Dedicated to Gerold Schwarzenbach, Exper. Suppl. IX, Birkhäuser Verlag, Basel 1964, 39.

19. Pecsok, R. L. and Bjerrum, J. Acta Chem. Scand. 11 (1957) 1419.

20. Andersen, P., Berg, T. and Jacobsen, J. Acta Chem. Scand. A 29 (1975) 381.

21. Schwarzenbach, G. Helv. Chim. Acta 36(1953) 23.

22. Schwarzenbach, G. and Magyar, B. Helv. Chim. Acta 45 (1962) 1454.

23. Mønsted, $\mathrm{O}$. and Bjerrum, J. Proceedings of the XIth. ICCC, Elsevier, Amsterdam 1968, 103.

Received September 1, 1981. 